\title{
PLUTONIUM HANDLING FACILITIES FOR RADIOGRAPHY
}
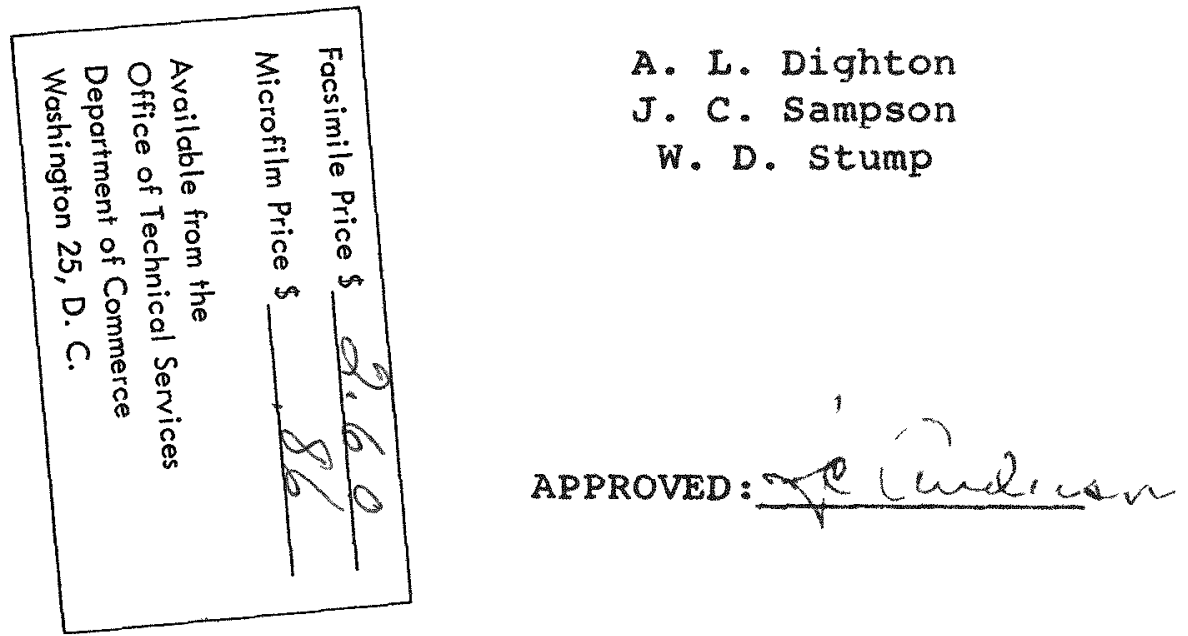

\section{MASTER}

Apri1 12, 1962

L. A. Matheson - Technical Director

J. G. Epp - Asst. Tech. Director

H. C. Anderson - Analytical Laboratory Director

\section{THE DOW CHEMICAL COMPANY \\ Rocky Flats Division \\ Denver, Colorado}

contract $\operatorname{AT}(29-1)-1106$
This paper as submitted for publication in the open luteraturg at least 6 months prior to the 18suance date of this Mucrocard. Since the U.S.A.E.C. has no evi-dence that it has been published, the paper is being distributed in Mucrocard form as a preprint. 


\section{DISCLAIMER}

This report was prepared as an account of work sponsored by an agency of the United States Government. Neither the United States Government nor any agency Thereof, nor any of their employees, makes any warranty, express or implied, or assumes any legal liability or responsibility for the accuracy, completeness, or usefulness of any information, apparatus, product, or process disclosed, or represents that its use would not infringe privately owned rights. Reference herein to any specific commercial product, process, or service by trade name, trademark, manufacturer, or otherwise does not necessarily constitute or imply its endorsement, recommendation, or favoring by the United States Government or any agency thereof. The views and opinions of authors expressed herein do not necessarily state or reflect those of the United States Government or any agency thereof. 


\section{DISCLAIMER}

Portions of this document may be illegible in electronic image products. Images are produced from the best available original document. 


\section{ABSTRACT}

Plutonium is a radioactive material, hazardous to personnel, therefore precautions must be taken to prevent contamination. since any radiography must be performed in an enclosed system, an enclosed glove box was constructed to facilitate radiographic operations. Tests show that no significant detail is lost in radiographing dense materials greater than 0.020 inch through 0.120 inch of aluminum using energies in the $1 \mathrm{MEV}$ range.

\section{ACKNOWLEDGMENT}

The writers appreciate the assistance given by Dr. G. H. Tenney and Mr. D. E. Elliott, Los Alamos Scientific Laboratory, GMX-1, in the preparation of this paper. 
1. PURPOSE

The purpose of this paper is to discuss a specific plutonium facility for radiography and cover some considerations in designing such a facility as well as to mention possible alternate methods. Some of the criteria which govern the design for handling bare plutonium pieces could possibly be utilized when handing other toxic materials.

\section{INTRODUCTION}

Plutonium is a potent alpha emitter and must be handled in an enclosed system. The most hazardous means of entrance of plutonium into the body is through inhalation. Because the inhalation of plutonium particulates is extremely hazardous to personnel the material must be handled in an enclosed system. No attempt will be made in this paper to discuss body damage incurred by inhalation or injection of plutonium.

The plutonium oxide which forms rapidly on exposed plutonium is non-adherent and easily spread. In order to prevent a spread of contamination the oxide must be either removed or covered before further operations can be performed. 
Either tape or paint may be used as a masking material and the choice would probably depend upon the size and type of surface area.

Normally bare plutonium is handled in an enclosed conveyor line with either glove ports or remote handling equipment. The pressure in the enclosed box is maintained at a pressure approximately $1 / 2$ inch of water lower than the outside pressure so that in the event of leaks or ruptures loose contamination will tend to xemain within the box. In the event it is necessary to remove such bare plutonium pieces from the enclosed system, the piece must be enclosed in another air tight system such as a plastic bag or other suitable container. Inasmuch as plutonium is a high density material (density 15-20) the thin sections of the plastic bag material do not significantly reduce the quality of the radiograph even though the folds of the plastic might be readily noticeable. However, the plastic can be readily ruptured when handling pieces with sharp edges and a considerable amount of handing time is involved in placing pieces in plastic bags using adequate sealing methods.

Consideration could also be given to the use of boxes of Low density material (such as aluminum) capable of handing two or more pieces at one time so that the sealing operation 
would not be necessary for each individual item. In this case a plastic sleeve could be connected between a port on the special aluminum container and the take-out position and, of course. would only necessitate sealing once per box containing several pieces, instead of each individual item. If all parts to be radiographed are identical, consideration might be given to special take-outs which would use containers which are designed to properly hold the piece for radiography and yet plug into the enclosed conveyor facility in such a manner that a positive seal is maintained during the take-out operation. This method is particularly feasible when the pieces are quite small so that easily obtainable containers, such as plastic vials, can be readily adapted for use.

\section{DISCUSSION OF FACILITY}

The radiographic facility upon which this discussion is based is the same as that necessary for using I-Mev radiation under normal industrial conditions (see radiographic area drawing Figure 1). However in setting up and handing of plutonium pieces the previously mentioned precautions must be observed. To reduce handing time and the possibility of contamination incidents, the "Lazy Susan" glove box for 
plutonium radiography was designed (see Figures 2 and 3 ). This glove box is made of plexiglass (or lead impregnated glass) and aluminum, is air tight, and is maintained under the same conditions as the balance of the glove conveyor line. The Lazy Susan unit is basically a doughnut shaped glove box with a turntable for moving the parts to their respective stations. There are eleven such stations on this box where the film can be placed on the outside perpendicular to the radiation. The photographs and drawings show a slight angle to the glove box wall where the film is placed. This is to compensate for "heel effect" and take advantage of the greater concentration of radiation about $10 \mathrm{deg}$ above the horizontal when the reflected beam of a General Electric I-Mev X-ray unit is used. (The outside wall of the glove box is set 10 deg forward from the vertical. Which makes the film perpendicular to the central rays.) In the event that a Lazy susan type box were designed for isotope radiography, the walls of the box should be constructed vertica11y.

Inasmuch as pieces may be radiographed using either 1 -Mev $x-r a y$ or cobalt-60 radiation a plastic bag take-out is provided in the line adjacent to the box (see Figure 4) so that pieces can be removed from the box system and moved into an adjacent cobalt-60 facility. 
Since the box is doughnut-shaped the target of the $x-x$ ay unit is placed inside the doughnut. The radiation then passes through the aluminum panel on the inside of the doughnut, through the part, through the outside aluminum panel, and onto the film. The aluminum panels on the inner and outer portion of the box are approximately 0.060 inch thick.

Inasmuch as it is necessary to move bare plutonium pieces through an enclosed conveyor line, it is necessary that means be provided for properly shielding the conveyor line exit and entrance when the $\mathrm{x}-\mathrm{xay}$ unit is in operation. Protection for personnel in this installation is provided by a 4 -inch lead door which opens inside the closed conveyor box for movement of pieces, but is closed during radiographic operation (see drawing of this entrance figure 5). As an added precaution a lead sleeve about 18 inches long and 3 inches thick is also in the wall (Figure 6). The concrete walls through most of this structure are $4 \mathrm{ft}$ thick and the inside of the room is $25 \times 36 \times 18 \mathrm{ft}$ high. Figures 6 and 7 show the lead door inside the conveyor line both in the opened and closed positions. In Figure 6 , with the door open, the line into the 1-Mev $X-r a y$ room is visible through the wall openung.

The object is brought through the entrance door on a roller conveyor. (Figures 6 and 7) Rollers of approximately 2-inch diameter, rather close together, are in the bottom of 
the conveyor line. Containers with items to be radiographed can be pushed along this line very easily and without danger of damaging the pieces if moderate care is exercised.

To perform the operation, as pieces are passed in through the lead door, through the vault wall and into the radiographic line, they are placed on the turntable inside the Lazy susan box. An intercommunication system may be noted in Figure 8 and is used by personnel when passing pieces to prevent damage and potential criticality incidents. Such criticality incidents are possible when an excessive mass of plutonium is placed within certain geometries. For further information on criticality the Nuclear Safety Guide may be used as a reference The pieces are placed on the pushbutton controlled turntable and then are rotated to their respective setup positions. Once at the stations, they are set up in a conventional mannex by means of the glove ports above each setup position. Inasmuch as such items as lead identification numbers on tape are difficult to handle with gloves, tweezers are generally used. After radiography the pieces are moved back through the wall in

(1) A. D. Callihan, ORNL, W. J. Ozeroff, HAPO, H. C. Paxton, LASL, C. L. Schuske, RFP. "Nuclear Safety Guide", USAEC report, TID-7016, 1958. (Unclassified) 
the same manner as previously described. The actual radiography of plutonium was thoroughly discussed in a paper by G. H. Tenney and D. E. Elliott, (2) therefore no attempt will be made here to detail the actual radiography; however, Figures 9, 10, and 11 show a comparison of setups of a normal or standard operation, using plastic bags and using the glove box. Since the area would become contaminated if plutonium were used in a standard setup, a 1/2-inch lead block was used for all of the setups shown.

The glove box photograph was made with the camera looking down into the box between the two glove ports, with the label on top of the box and the piece inside at a regular setup position. The piece being radiographed in thie photographs is resting on soft material which is covered with tissue; also, a tissue is placed behind the piece. The tissues help prevent scratching or damaging the piece as well as tending to contain particles of plutonium.

Radiographs were taken under these setup conditions for comparison of resolution and scatter to determine minimum thickness of plutonium radiographable in the existing equipment which was constructed primarily according to mechanical rather

(2) G. H. Tenney, D. E. Elliott, "Radiography and Autoradiography of Plutonium", Nondestructive Testing, Vol. XVI, No. 5, pp. $430-437$. 
than radiographic criteria.

\section{CONCLUSION}

While reproduction of radiographs (Figure 12) always results in some loss of detail, the original radiographs indicate that no significant loss of detail is encountered when sections of plutonium 0.020 inch or thicker are radiographed through 0.120 inch of aluminum using energies in the 1-Mev range. Mechanical criteria for the glove box construction appear adequate for any predictable needs. 


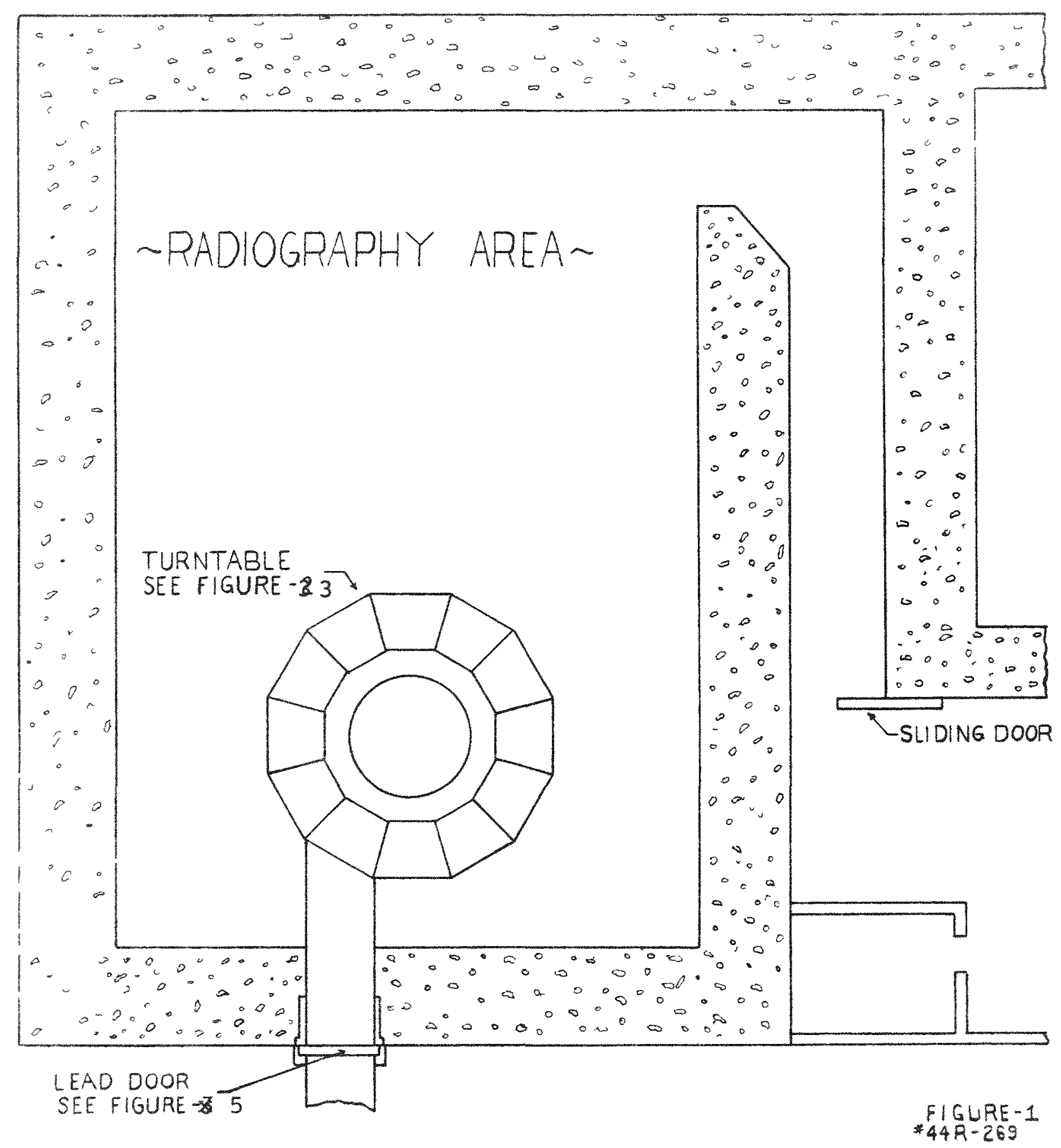




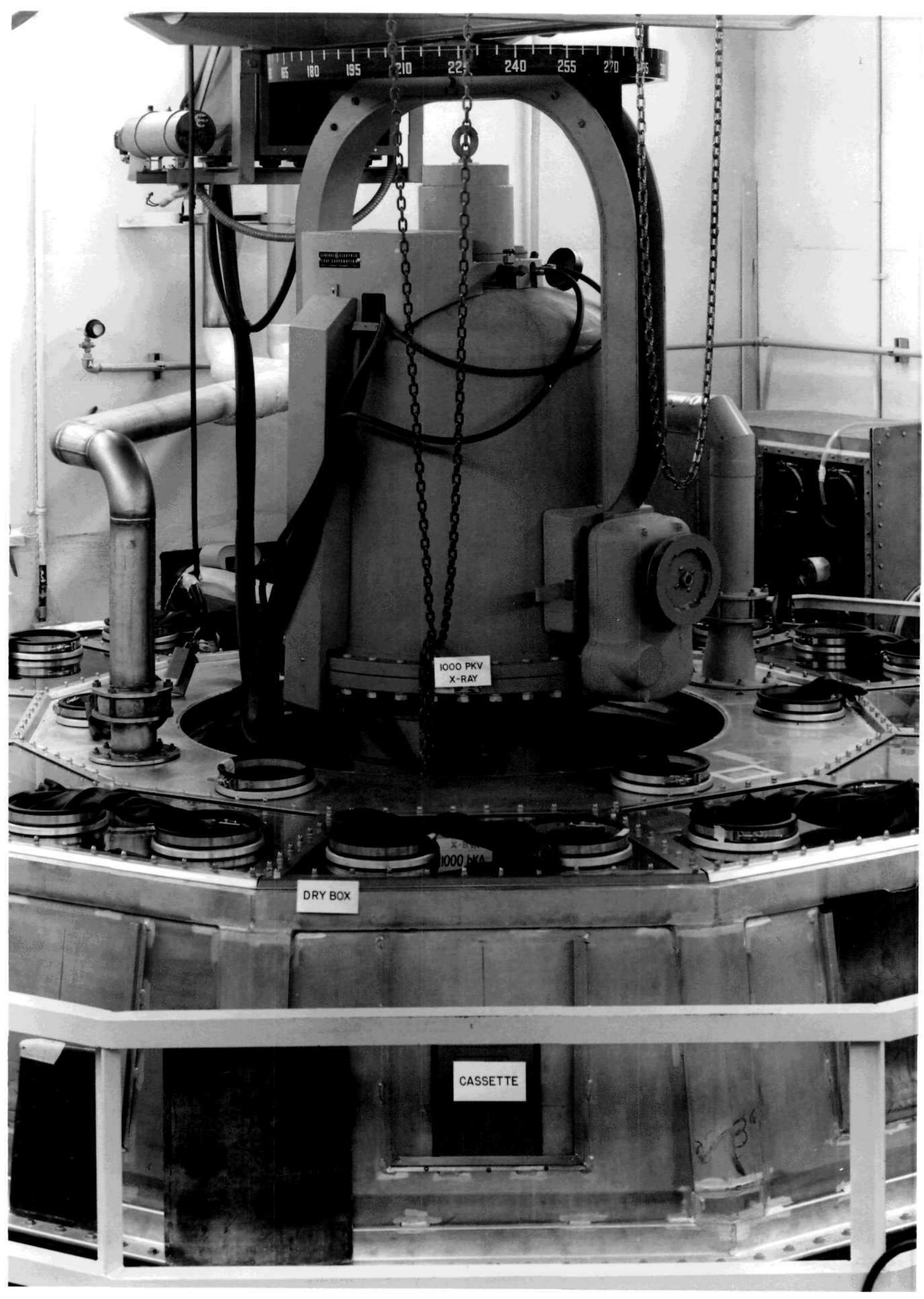




\section{PHOTO- LAB \\ THE DOW CHEMICAL COMPANY \\ ROCKY FLATS \\ NFE 3609 \\ PLEASE REORDER BY NUMBER}




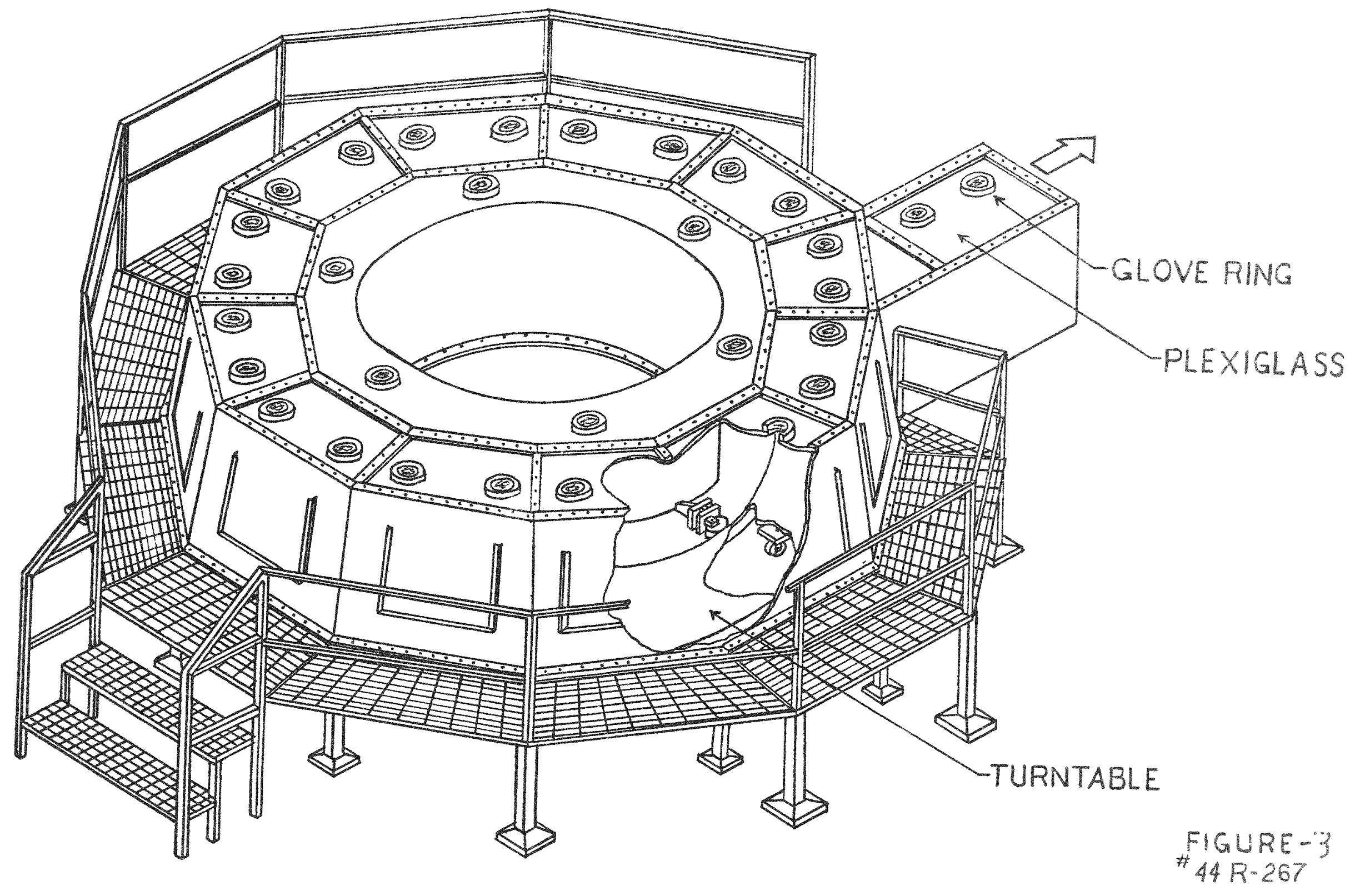

Figure 3

Lazy Susan Box Drawing 


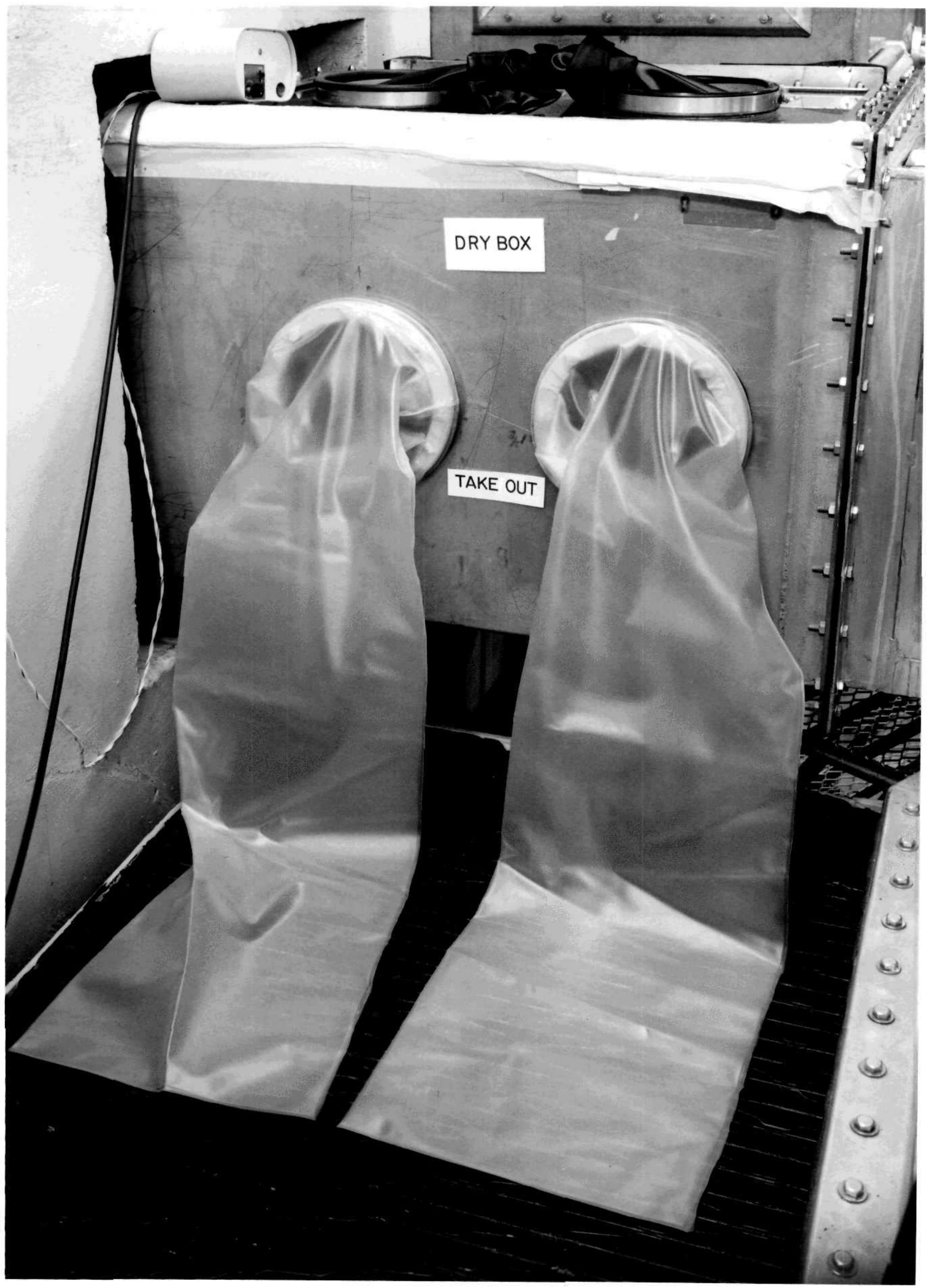




\author{
PHOTO-LAB \\ THE DOW CHEMICAL COMPANY \\ ROCKY FLATS \\ NFG 3951 \\ PLEASE REORDER BY NUMBER
}




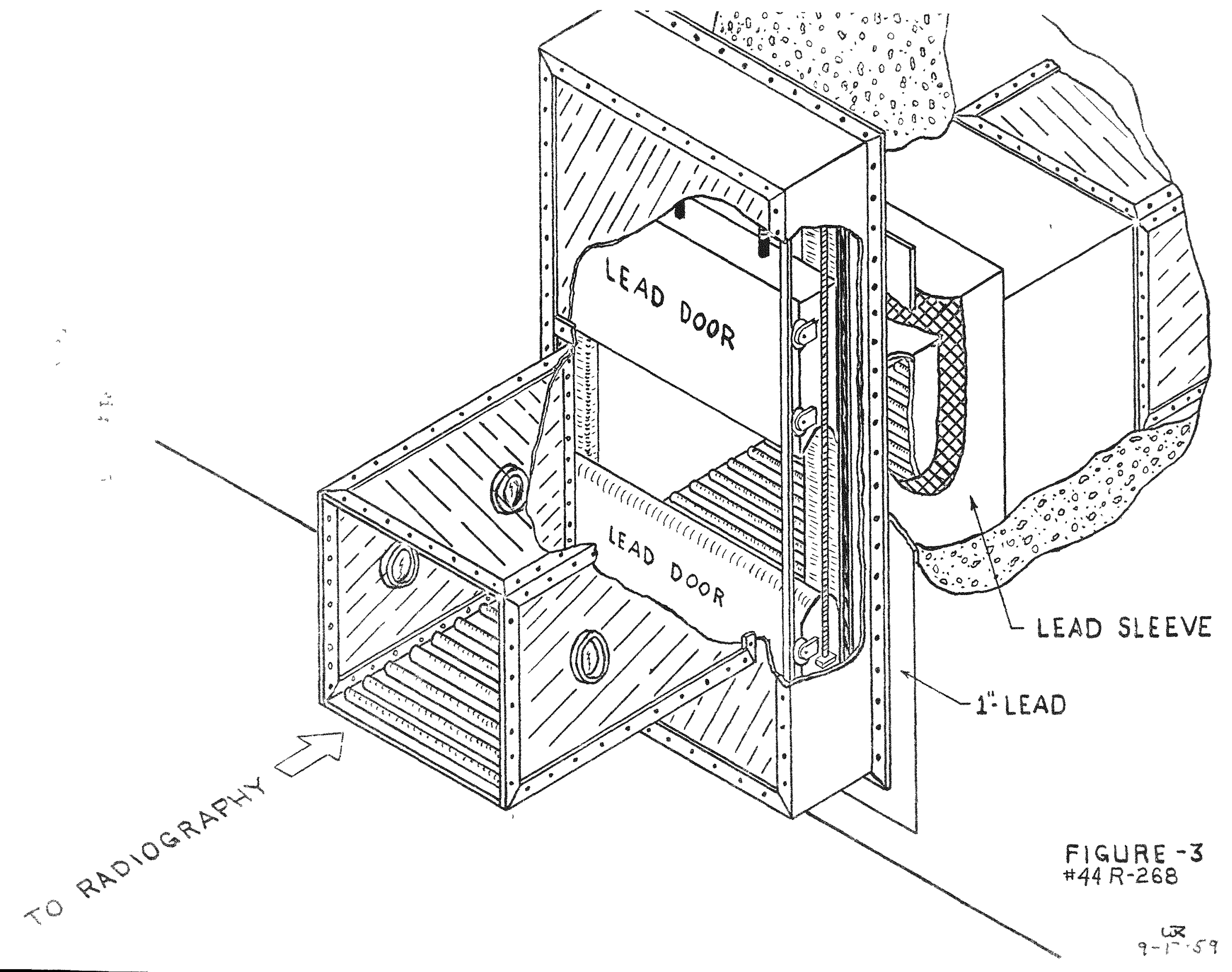




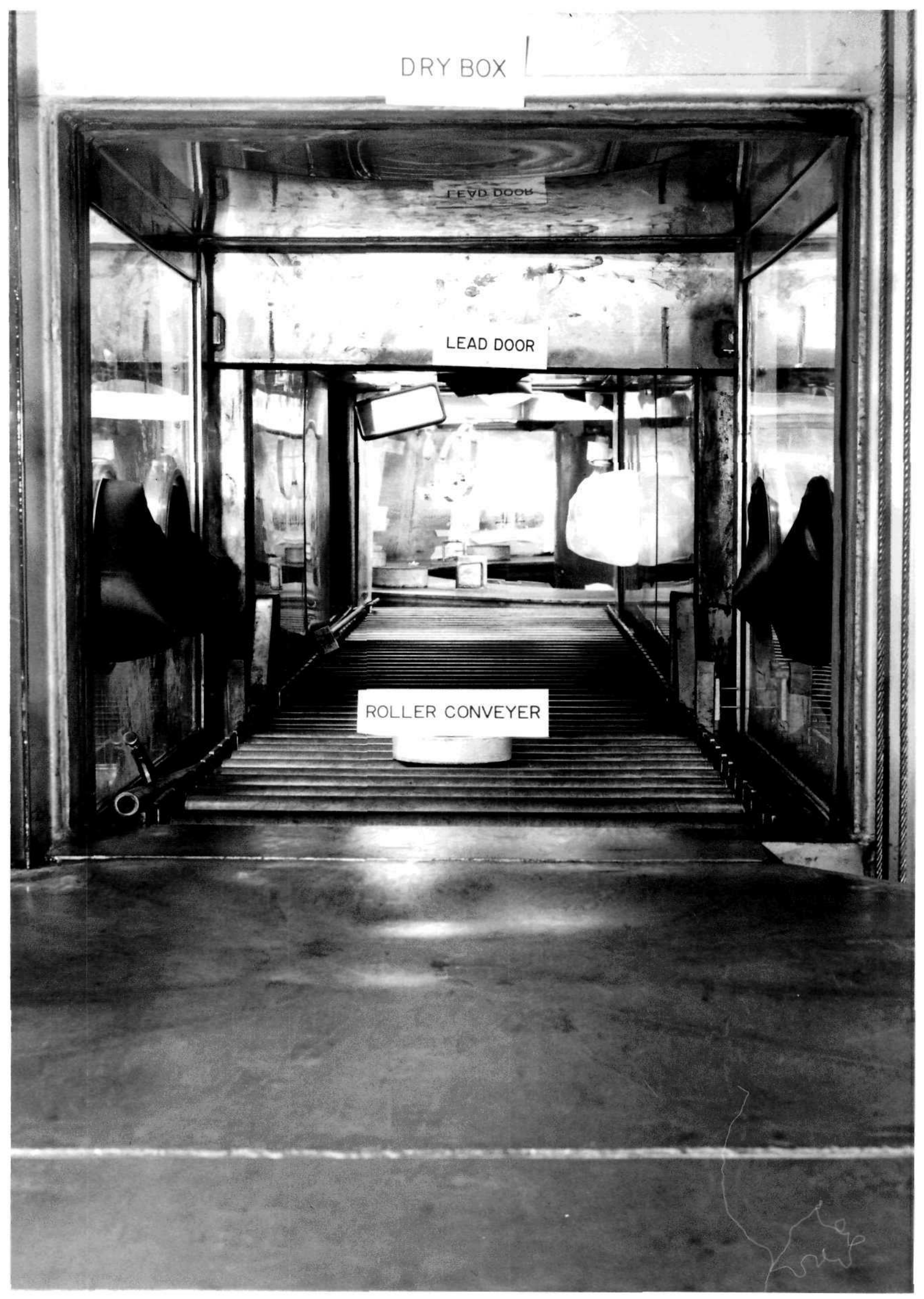




\section{PHOTO-LAB \\ THE DOW CHEMICAL COMPANY \\ ROCKY FLATS PLANT}

NEG 4393

\section{PLEASE REORDER BY NUMBER}




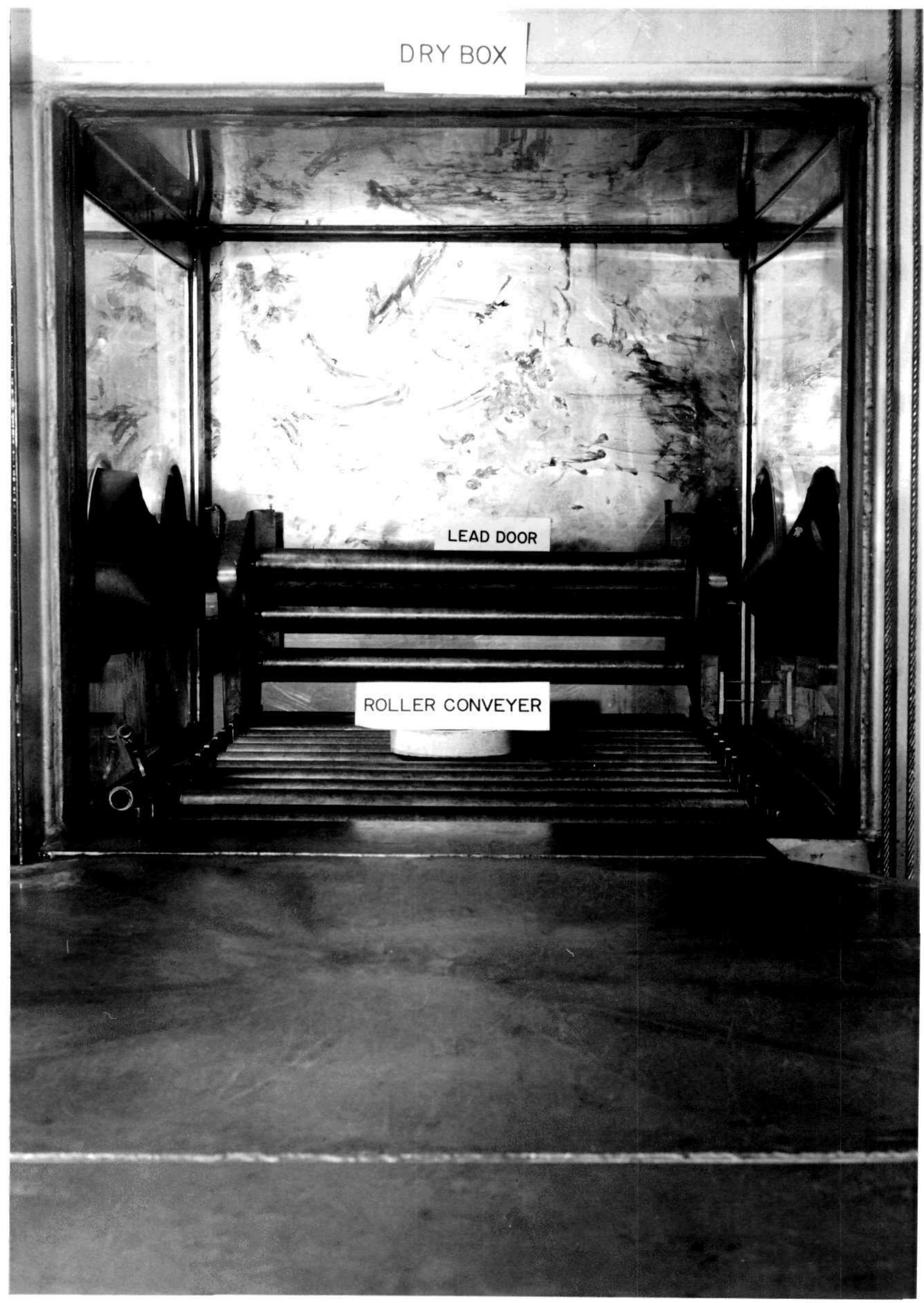




\section{PHOTO - LAB \\ THE DOW CHEMICAL COMPANY \\ ROCKY FLATS PLANT \\ NEG 4392 \\ PLEASE REORDER BY NUMBER}




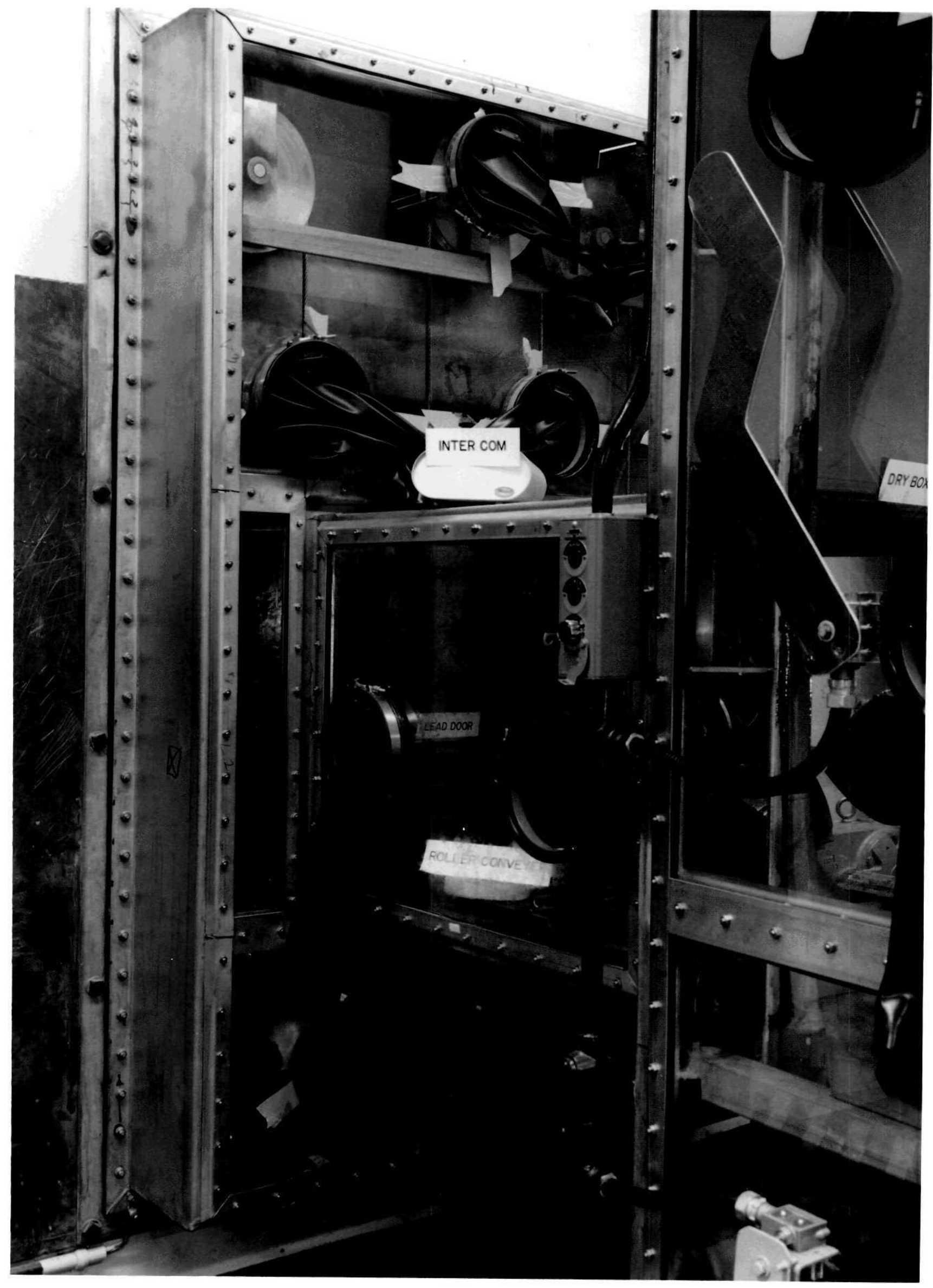





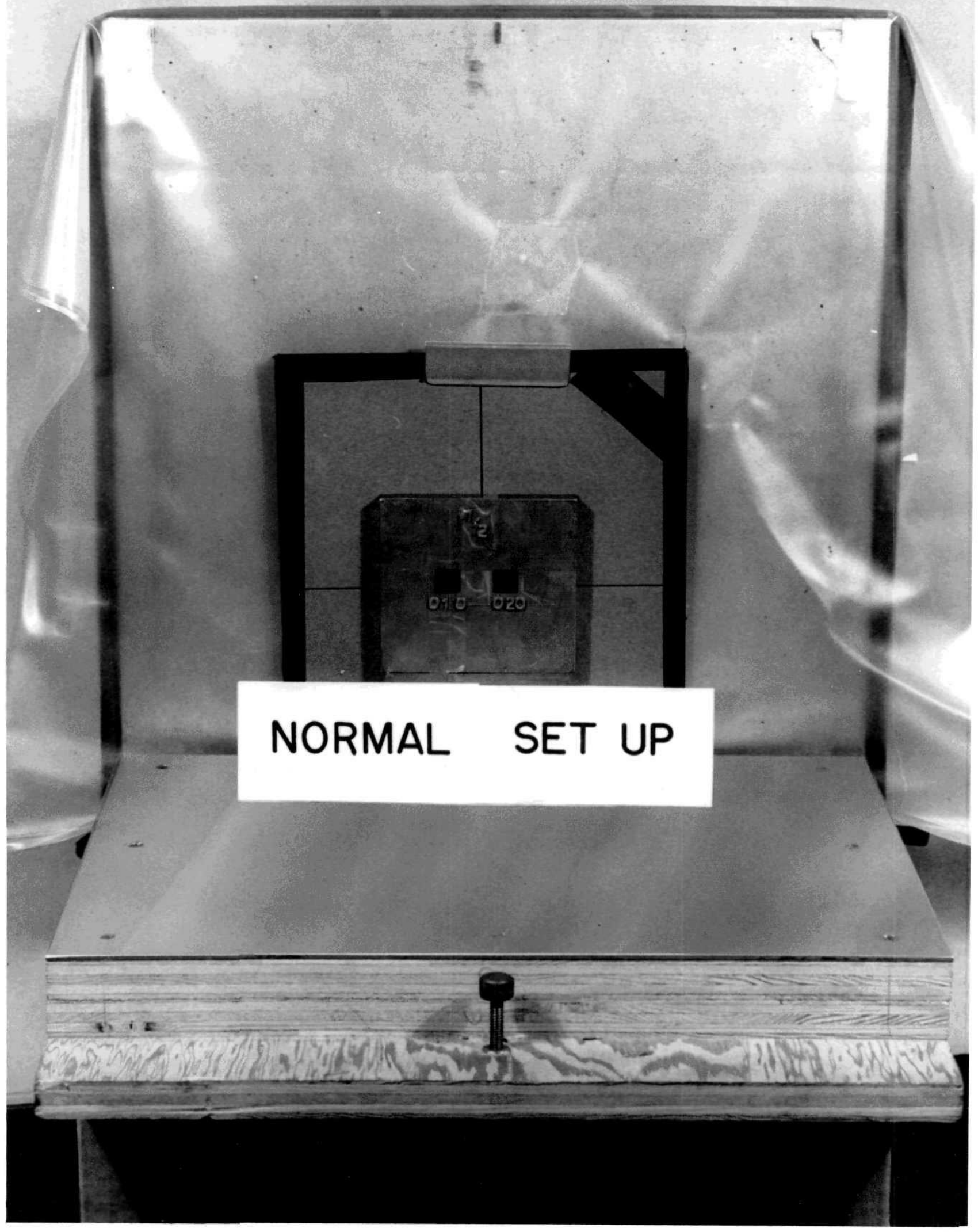




\author{
PHOTO- LAB \\ THE DOW CHEMICAL COMPANY \\ ROCKY FLATS \\ NEG 4386 \\ PLEASE REOREER BY NUMBER
}




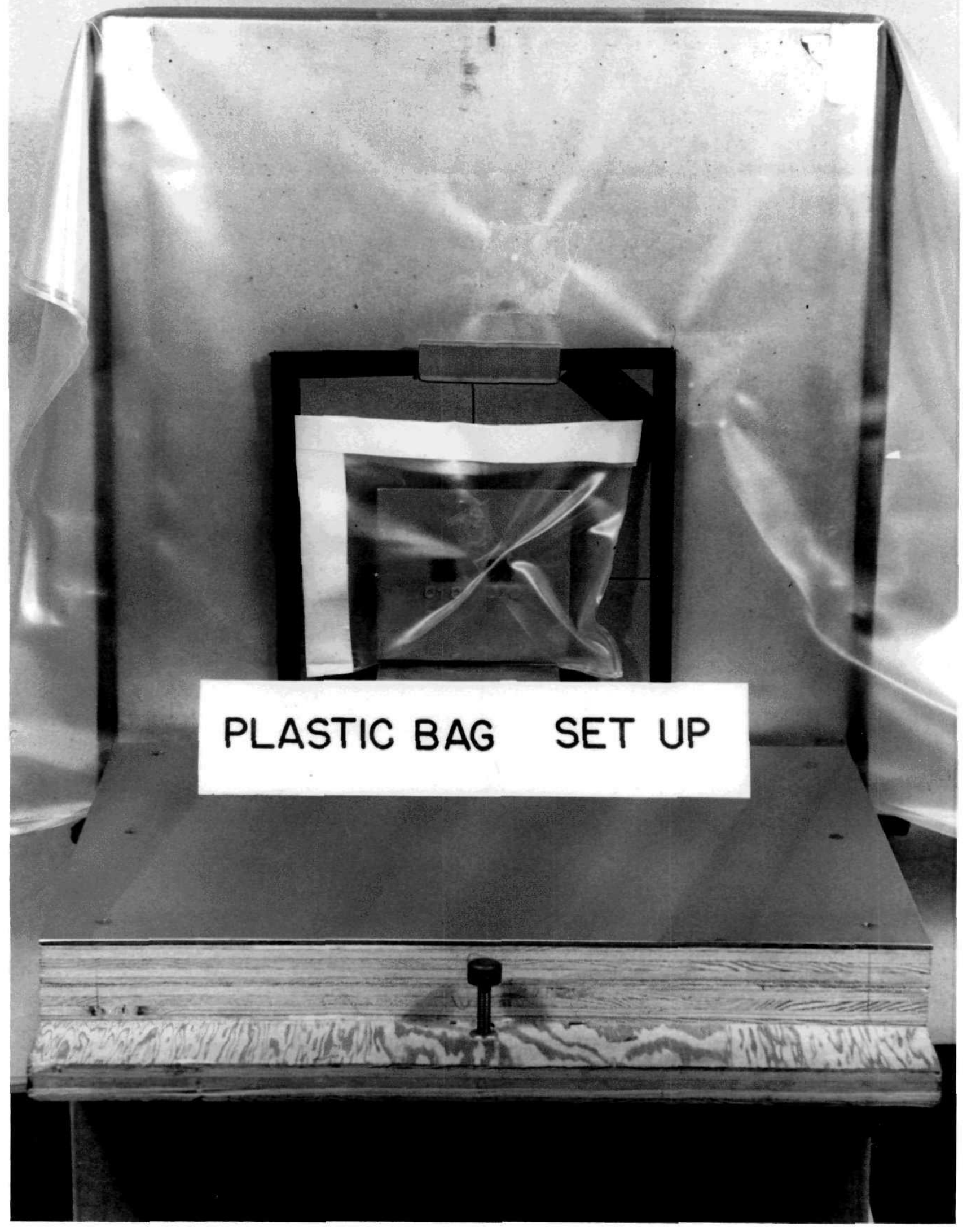




\section{PHOTO - LAB \\ THE DOW CHEMICAL COMPANY \\ ROCKY FLATS \\ NEG $438 \%$ \\ PLEASE REORETR BY NUMBER}




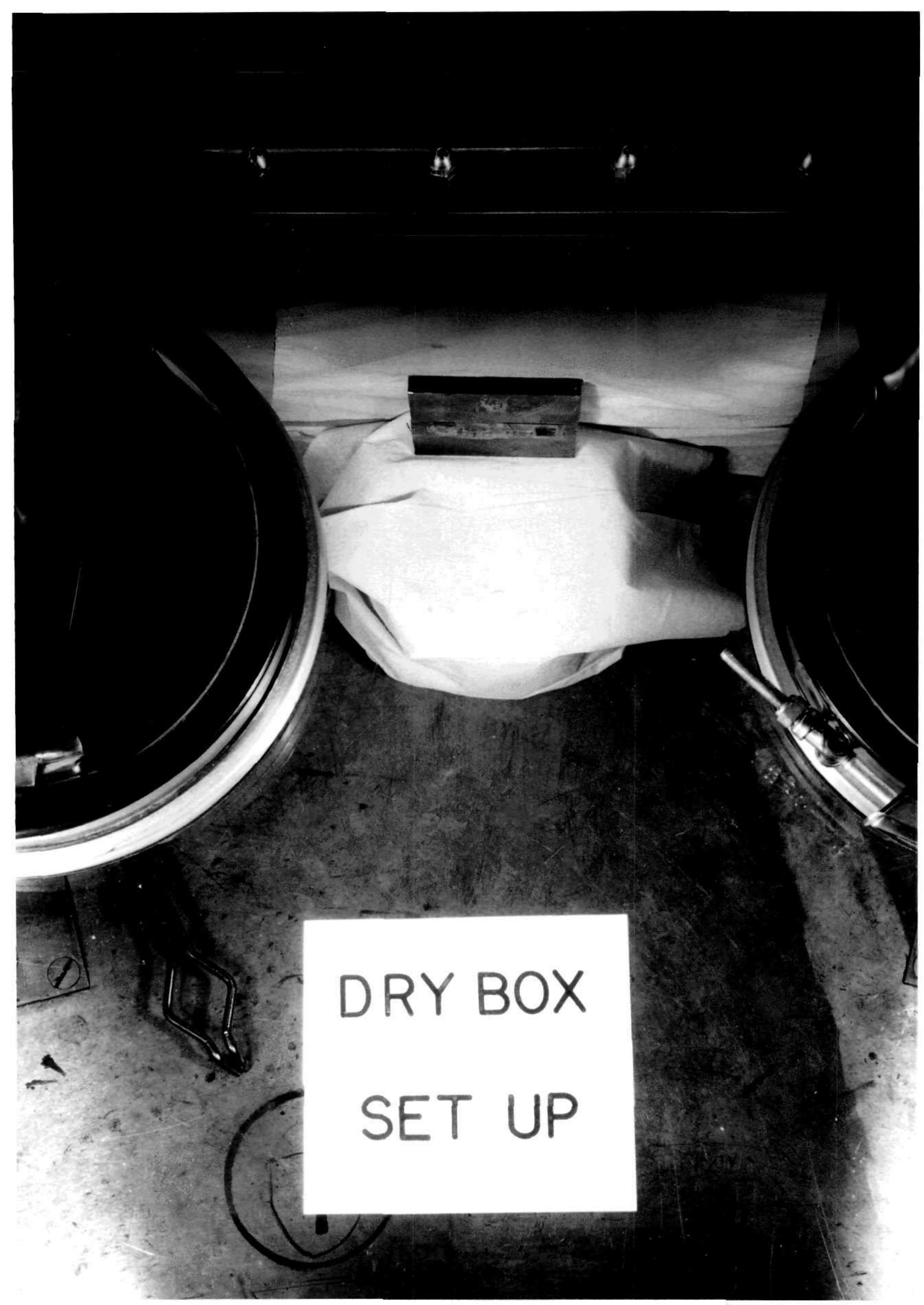




\section{PHOTO - LAB}

THE DOW CHEMICAL COMPANY

ROCKY FLATS PLANT

NEG 4.388

PLEASE REORDER BY NUMBER' 


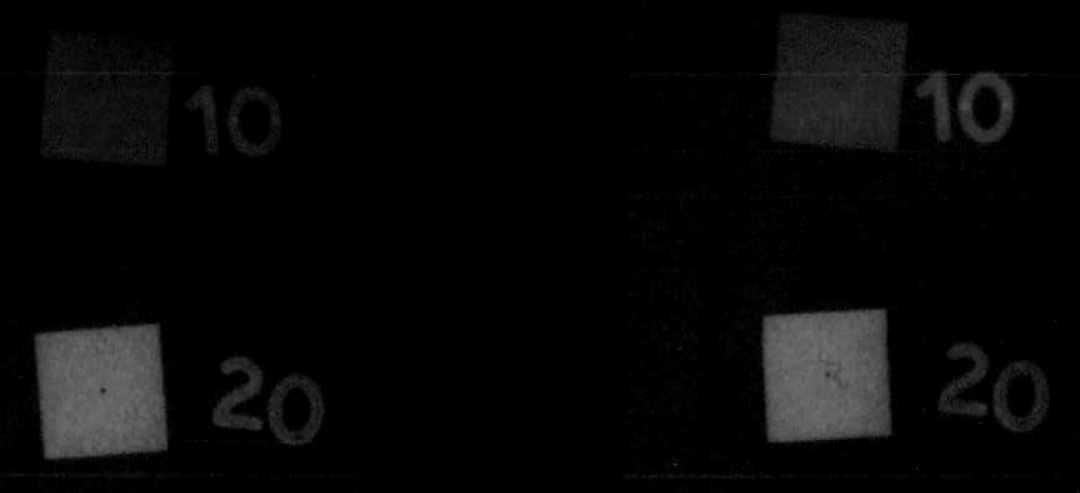

